\title{
Articles
}

\section{Corporate Moral Agency and the Responsibility to Respect Human Rights in the UN Guiding Principles: Do Corporations Have Moral Rights?}

\author{
Patricia H WERHANE*
}

\begin{abstract}
In 2011 the United Nations (UN) published the 'Guiding Principles on Business and Human Rights: Implementing the United Nations "Protect, Respect, and Remedy" Framework' (Guiding Principles). The Guiding Principles specify that for-profit corporations have responsibilities to respect human rights. Do these responsibilities entail that corporations, too, have basic rights? The contention that corporations are moral persons is problematic because it confers moral status to an organization similar to that conferred to a human agent. I shall argue that corporations are not moral persons. But as collective bodies created, operated, and perpetuated by individual human moral agents, one can ascribe to corporations secondary moral agency as organizations. This ascription, I conclude, makes sense of the normative business responsibilities outlined in the Guiding Principles without committing one to the view that corporations are full moral persons.
\end{abstract}

Keywords: corporate moral agency, corporate moral rights, human rights

\section{Introduction: Corporate Human Rights Obligations as a Double-Edged Sword}

In 2011 the United Nations, under the guidance of Special Representative of the Secretary-General for Business and Human Rights, John G. Ruggie, published the 'Guiding Principles on Business and Human Rights: Implementing the United Nations "Protect, Respect, and Remedy" Framework' (Guiding Principles). These are a set of principles spelling out the respective duties and responsibilities of governments and businesses to 'respect, protect and [when necessary] remedy violations of human rights'. These are voluntary guidelines with no legal enforcement mechanisms, and they apply to all nation-states and to all business enterprises, including corporations.

This article argues that if, as the Guiding Principles specify, for-profit corporations have responsibilities to respect human rights, then those whose rights are to be respected by corporations have reciprocal obligations to respect corporate rights. This is because,

* Wicklander Chair Emerita, DePaul University and Ruffin Professor Emerita, University of Virginia, USA. My deep thanks to the editors of the Journal, Michael Santoro and Florian Wettstein for their numerous extraordinarily helpful comments and additions. The errors are unfortunately my own. 
as I shall argue, human rights entail reciprocal responsibilities. However, this conclusion leads us to a set of difficult issues. Does it make sense to say that corporations have moral rights? Ordinarily, the notion of a human right concerns either relationships between individual moral agents (usually specified as adult sane individuals), or legal entitlements guaranteed by law and/or by nation-states, or in some cases, by all of the above. But corporations are not literally human beings. So the reciprocal relationships between rights bearers, if there are such, would entail (i) ascribing to corporations the same qualities of moral agency that we ascribe to adult human beings or (ii) contending that such obligations do not apply to corporations vis-à-vis individual human beings, thus would not be moral obligations but rather social expectations, or (iii) that such obligations, if they are social expectations rather than moral obligations, as the Guiding Principles seem sometimes to suggest, would have to be guaranteed by law and nationstates. But, as the Guiding Principles state, corporate responsibilities to respect human rights are voluntary - that is, not necessarily enforced as legal demands on business. In other words, (iii) does not apply. This voluntarism of responsibilities, then, implies that they are merely social expectations (ii), or normative claims (i). If it is the latter, then this implies that corporations, like individuals, are moral agents who can be responsible and, as such, subjects of rights claims. The contention that corporations are moral persons is problematic because it confers moral status on an organization similar to that conferred on a human agent. On the one hand, this status may give corporations a great deal in the way of rights, rights unequal to and greater than those of ordinary moral individuals. On the other hand, this moral status may merely be applicable to the individuals who are constituents of, or agents for, an organization. If so, then we would merely aggregate or bundle these moral rights of individuals and for convenience call them 'corporate rights'. But that conclusion is problematic as well, because then one cannot hold a corporation as an institution morally responsible, but merely the individuals who are agents for, and constituents of, that organization.

Given this set of thorny issues, I shall present a way out of these dilemmas. I shall argue that corporations are not moral persons or individual moral agents. But as collective bodies created, operated, and perpetuated by individual human moral agents, one can ascribe to corporations secondary moral agency as organizations. This ascription, I will conclude, makes sense of the normative business responsibilities outlined in the Guiding Principles without committing one to the view that corporations are full moral persons. ${ }^{1}$

In what follows, Section II sets out the question of corporate obligations to respect human rights. Section III traces the origins of the notion of corporate personhood. Section IV outlines an account of basic human rights, which, it turns out, are importantly and primarily normative, moral rights. Sections V and VI address the issues of corporate moral agency and corporate moral rights. Section VII addresses the question of corporate moral rights. The article concludes with addressing the implications of the argument for the propositions of the Guiding Principles.

\footnotetext{
1 In this article I shall only focus on for-profit corporations, and I shall use the terms 'corporation' and 'organization' interchangeably. I recognize that not all organizations are corporations, and that there may be different criteria for moral agency in various organizations. That is a topic for another article.
} 


\section{Do Corporations Have Responsibilities to Respect HuMAN Rights?}

The Guiding Principles state:

These Guiding Principles are grounded in the recognition of

(a) States' existing obligations to respect, protect, and fulfil human rights and fundamental freedoms;

(b) The role of business enterprises as specialized organs of society performing specialized functions, required to comply with all applicable laws and to respect human rights....

Business enterprises should respect human rights. This means that they should avoid infringing on the human rights of others and should address adverse human rights impacts with which they are involved ... The responsibility to respect human rights is a global standard of expected conduct for all business enterprises wherever they operate. It exists independently of States' abilities and/or willingness to fulfil their own human rights obligations, and does not diminish those obligations. And it exists over and above compliance with national laws and regulations protecting human rights. ${ }^{2}$

Note the normative language of the Guiding Principles: 'Business enterprises should ...' Although the next line states, 'The responsibility to respect human rights is a global standard of expected conduct ...', thus outlining societal expectations, the terms 'should', 'responsibility', and later, 'obligations' are normative and imply moral responsibilities on the part of businesses as well as what society expects. Moreover, these responsibilities involve more than merely respect. It extends to 'mitigat [ing] adverse human rights impacts that are directly linked to their operations, products or services by their business relationships, even if they have not contributed to those impacts'. ${ }^{3}$ As Wettstein points out, ${ }^{4}$ these obligations parallel Henry Shue's earlier claim that rights entail three kinds of duties: avoid deprivation of human rights ('avoid infringing on the human rights of others'), protect human rights ('address adverse human rights impacts ...'), and aid those who have suffered from 'adverse human rights impacts'.

One justification for these principles, as Tom Donaldson once argued based on social contract theory, is that because corporations are allowed by communities to do business, they have reciprocal obligations to those communities. ${ }^{6}$ The Guiding Principles make a similar argument: 'The role of business enterprises as specialized organs of society performing specialized functions, required to comply with all applicable laws and to respect human rights'.

2 Human Rights Council, 'Guiding Principles on Business and Human Rights: Implementing the United Nations

"Protect, Respect and Remedy” Framework', A/HRC/17/31 (21 March 2011) 1, 13.

3 Ibid, 14.

4 Florian Wettstein, 'CSR and the Debate on Business and Human Rights: Bridging the Great Divide' (2012) 22 Business Ethics Quarterly 739.

5 Ibid; Henry Shue, Basic Rights (Princeton: Princeton University Press, 1980).

6 Tom Donaldson, Corporations and Morality (Englewood Cliffs NJ: Prentice-Hall, 1982).

7 Human Rights Council, note 2, 14 (my italics). 
Expanding on that point, one might argue, for example, that because companies often have broad impacts on the communities in which they operate or trade, as 'specialized organs of society', they must have obligations to those communities in return. But as an 'organ of society' and not a human being, these are not necessarily moral responsibilities to respect human rights and mitigate their violations. Such responsibilities can also be thought of as more utilitarian. Companies are allowed to operate in communities and as collective members of a society they owe reciprocal paybacks for permissions to operate. But these 'paybacks' may be in terms of hiring local people, building roads, providing clinics for workers, etc. They do not necessarily entail respecting human rights unless that is an expectation of that community or a part of the bargaining proposition between the company and the community.

Another utilitarian defence of ascribing to corporations responsibilities to respect, defend, and mitigate human rights derives from their extensive power and economic control in society. Such power and control then require that corporations respect human rights. ${ }^{8}$ But, again, why do power and economic control entail these sorts of responsibilities? On their own, power and economic largesse do not provide the justification, much as we might wish, for demanding that companies respect human rights.

Donaldson does not defend this utilitarian position, nor shall I. But in order to make a case for the Guiding Principles, one has to make sense of the status of corporations as agents. Before the Guiding Principles were published, in 1994 Donaldson argued that corporations, particularly in their international operations, should respect and even protect human rights in those communities in which they operate. ${ }^{9}$ But the problem is this: if Donaldson is correct, then does it follow that corporations have reciprocal rights claims as well? While we might like companies to have such responsibilities, how can we defend the position that they, as organizations, have obligations to respect human rights? What are such obligations based upon? And in communities where there is little in the way of a rule of law and enforcement of even minimum human rights, why do companies operating in such communities have any obligations to protect human rights? ${ }^{10}$ To see how this works out, let us look at the origins of the idea of corporate personhood.

Another question one should consider in analysing the moral status of the Guiding Principles is whether basic human rights entail perfect duties? Although some philosophers tend to use the terms 'responsibilities', 'obligations', and 'duties' interchangeably, there are nuances that should be acknowledged. The term 'duty' is often equated with a perfect duty. A perfect duty is a duty, the violation of which is always wrong. Thus, by this account a perfect right is a right wherein violations always morally require redress. ${ }^{11}$ An imperfect duty is more voluntary. It spells out what one ought to do, all things considered, where exceptions are permissible. For example it is always wrong

\footnotetext{
8 See Wesley Cragg, 'Human Rights, Globalization, and the Modern Corporation' in Tom Campbell and Seamus Miller (eds.), Human Rights and the Moral Responsibilities of Corporate and Public-Sector Organizations (Dordrecht: Kluwer, 2004); LW Sumner, The Moral Foundations of Rights (Oxford: Clarendon Press, 1987).

9 Tom Donaldson, The Ethics of International Business (New York: Oxford University Press, 1989).

10 Denis Arnold, 'Transnational Corporations and the Duty to Respect Basic Human Rights' (2010) 20 Business Ethics Quarterly 371.

11 See Adam Smith, Lectures on Jurisprudence, R L Meek and D D Raphael (eds.) (Oxford: Oxford University Press, 1978); Florian Wettstein, 'Normativity, Ethics, and the UN Guiding Principles on Business and Human Rights: A Critical Assessment' (2015) 14(2) Journal of Human Rights 162.
} 
to deliberately murder another human being, but self-defence is a permissible exception. The Guiding Principles are careful to make these distinctions. Business has responsibilities to respect human rights; states have duties to do so. ${ }^{12}$ Although this is not expressed explicitly in the Guiding Principles, one can extrapolate that states have perfect duties to protect human rights; corporations have imperfect duties, that is, responsibilities to respect human rights within their purview of operations, all things considered. This extrapolation does not dilute corporate responsibilities but places them in the context of practice.

\section{Origins of Corporate 'Personhood'}

The business corporation has a long history. According to one source:

The Roman Republic relied on private contractors to perform a variety of tasks. Contracts to build aqueducts, manufacture arms, construct temples, collect taxes-even feed the geese on the Capitol-were granted to firms called publicani. These originated as loose associations among contractors who would pool their resources to bid on contracts. Over time, the publicani evolved into permanent companies with numerous investors, only a handful of whom served as managers. Larger publicani employed thousands of workers spread across Rome's provinces. Fragmented evidence indicates that some of these received corporate status (habere corpus), which included a grant of limited liability for investors. ${ }^{13}$

Corporations in this form virtually disappeared in the Middle Ages, being replaced by guilds, monasteries, and universities, all serving public functions and chartered by the sovereign.

The modern corporation as it exists today is a fairly new idea, dating from the late sixteenth and early seventeenth centuries. One of the earliest and largest organizations of this sort was the English East India Company. In 1600 Queen Elizabeth I granted the status of 'joint-stock company' to the East India Company, which gave this organization virtual licence to operate without impunity in Asian territories now known as India. ${ }^{14}$ Joint-stock companies were partnerships granted permission to operate by the sovereign or state. Joint-stock companies differed from today's modern corporation in at least three respects. First, the partners (shareholders) were personally liable for losses as well as benefitting from profits. Second, in addition to economic activities, joint-stock companies were expected to engage in some social welfare activities, and third, at any time they could be shut down by the sovereign. ${ }^{15}$

Early companies in the United States were joint-stock companies. However, with industrialization in the nineteenth century and the growth of capital, that model

\footnotetext{
12 Human Rights Council, note 2, 5.

13 Risk Encyclopedia, 'History of Corporations', Risk Encyclopedia (n.d.), http://www.riskencyclopedia.com/articles/ corporation (accessed 23 July 2015).

14 In 1602 the government of Holland granted similar status to the Dutch East India Company, which operated similarly in the Dutch East Indies, known now as Indonesia. See Encyclopaedia Britannica, 'Dutch East India Company', Encyclopaedia Britannica (8 May 2015), http://www.britannica.com/EBchecked/topic/174523/DutchEast-India-Company (accessed 23 July 2015); Encyclopaedia Britannica, 'East India Company', Encyclopaedia Britannica (11 June 2015) http://www.britannica.com/EBchecked/topic/176643/East-India-Company (accessed 23 July 2015).

15 Archie B Carroll et al, Corporate Responsibility: The American Experience (Cambridge: Cambridge University Press, 2012).
} 
was changed. States rather than federal mandates were allowed to charter these organizations. These charters granted limited liability to the owner-shareholders and unlimited life to the organization. The proviso for doing some social welfare projects was also abolished. ${ }^{16}$

These new organizational formulations were solidified as independent bodies by an 1819 Supreme Court decision that ruled that the Trustees of Dartmouth College could act as a single entity to become property owners, thus with the rights to buy, sell, and trade properties. The decision included the conclusion that '[a] corporation is an artificial being, invisible, intangible, and existing only in the contemplation of the law' ${ }^{17}$ In 1886 another landmark Supreme Court Decision declared that joint-stock companies, corporations, and other chartered organizations have the same legal rights as individuals protected under the Fourteenth Amendment, which had originally been written to protect former slaves from discrimination and to endow them with rights to equal protection and due process. This decision thus granted corporations these same rights to due process, property, and equal protection. ${ }^{18}$ And in 1889 the Court ruled that corporations were legal persons. ${ }^{19}$ Although not granted rights to vote or hold office, in 1978 corporations were granted rights to free speech. ${ }^{20}$ Finally in 2010 the Court ruled that organizations including corporations, non-profit organizations, and unions could contribute to political campaign advocacy. ${ }^{21}$ Interestingly, in this last decision a corporation is defined as 'an association of individuals' ${ }^{22,23}$ But if corporations are associations-associations are merely aggregates of individuals - how then are they single-entity legal persons under the law? To date the American courts have not sorted out this anomaly, and in other decisions corporations are treated as legal persons.

There are at least two shortcomings of the previous outline. First, even if corporations are legal persons, this does not imply that they have any moral status. Legal personhood is a convenient mechanism, particularly in regard to large companies for which it is impossible to hold all individuals involved in a project liable. For example, the recent British Petroleum oil spill in the Gulf of Mexico caused the deaths of 11 oil workers (thus violating their rights to safe working conditions) as well as vast damage to properties and livelihoods of those living on the Gulf. But it is impossible to pinpoint all those individuals at BP and their sub-contractors who were at fault. The rig was made by a Korean firm, Hyundai, owned and operated by another company, Transocean, and leased to $\mathrm{BP}$. The CEO of BP, as head of that company, was held responsible, but there were thousands of others at BP, Transocean, and Hyundai, as well as other sub-contractors

\footnotetext{
16 Ibid; Lyman Johnson, 'Law and Legal Theory in the History of Corporate Responsibility: Corporate Personhood' (2012) 35 Seattle University Law Review 1521; Lyman Johnson, University of St. Thomas Legal Studies Research Paper No. 12-19.

17 Trustees of Dartmouth College v Woodward 17 US 518 (1819).

18 Santa Clara County v Southern Pacific Railway Company 118 US 394 (1886).

19 Minneapolis and St. Louis Railway Company v Beckwith 129 US 26 (1889).

20 First National Bank of Boston v Bellotti 435 S 765 (1978).

21 Citizens United v Federal Election Commission 130 S Ct 876 (2010); see also Carroll, note 15; Johnson, note 16; Eric Orts, Business Persons: A Legal Theory of the Firm (London: Oxford University Press, 2013).

22 Citizens United $v$ Federal Election Commission, note 21, 876.

23 This identification of corporations as associations of individuals in the Citizens United decision comes from the Syllabus and from Justice Scalia's concurring support of the decision.
} 
who participated in the construction and safety measures of that oil rig. Because we cannot track all those people down, we hold BP and, secondarily, Transocean responsible. $^{24}$ Treating a corporation as a legal person makes that possible. Legal personhood does not let individual corporate culprits 'off the hook', but sometimes we just do not know who they all are.

Second, this description deals only with the legal status of United States companies. Other countries may or may not treat corporations as legal persons. But, even if not every country recognizes corporations as legal persons, the idea that a corporation is a single entity has spilled over globally. Moreover, often the corporate status as a legal person spills over to imagining that corporations are moral persons as well. As a result, companies are often extended rights that ordinarily are reserved for individual persons. This 'single entity' concept brings us to the question of corporate rights and corporate moral personhood. But first let us analyse what we mean by a 'human' or 'moral' right.

\section{Basic Human Rights}

The argument that human beings have a set of basic rights just because they are human beings, or usually more specifically, adult sane human beings, has a short philosophical history. One might make a case that the twelfth century theologian, Thomas Aquinas, originated this idea, but usually one goes back to John Locke, a seventeenth century English philosopher, whose writings were Thomas Jefferson's inspiration for the American Declaration of Independence. Locke argued that just because we were born into that class of being-human being-we have basic, inalienable universal and God-given natural rights. These include obvious rights, beginning with the right to life. But in order to live, Locke argued, we have to work and to be paid for that work. Thus we also have the right to liberty in order to choose where we work, and because we have rights to work, we have natural rights to own and accumulate property. ${ }^{25}$ Locke's theory of rights also assumes that the rights he spells out include the power to exercise those rights.

Locke's articulation of a basic rights theory was adopted for the American Declaration of Independence and their Bill of Rights; it was in the background thinking also of the French Declaration of Man, later, in 1948, the United Nations Universal Declaration of Human Rights, and even later, the United Nations Global Compact (2000). In this evolution of rights talk, the references to 'God-given' and 'nature' are usually dropped to appeal to a more secular or religiously diverse audience. Thus Locke's term 'natural rights' has evolved to the term 'human rights'. Notice that all these documents are aspirational, setting out normative principles that should be incorporated and protected universally although with the acknowledgement that this is not in fact always the case. Thus often one uses the term moral rights to describe human rights.

There has been a vigorous debate as to what counts as a basic right. Some thinkers such as Robert Nozick argue that one can only make sense of human rights or moral

24 Richard Pallardy, 'Deepwater Horizon Oil Spill of 2010', Encyclopaedia Britannica (2 July 2015), http://www. britannica.com/EBchecked/topic/1698988/Deepwater-Horizon-oil-spill-of-2010 (accessed 23 July 2015).

25 John Locke, Two Treatises on Government, Peter Laslett (ed.) (Cambridge: Cambridge University Press, 1967). 
rights as negative rights, that is, as moral minimums for general human claims, such as, for example, the right not to be denied speech, property, life, or work. ${ }^{26}$ The United States Constitution and Bill of Rights, however, include positive rights such as the right to vote, to due process, and even the right to bear arms. These are called positive rights because they are claims to something, rather than merely negative prohibitions or 'nots'. 27 Other formulations such as the UN Declaration of Human Rights list both positive and negative rights and that document even includes the right to a holiday. The UN Global Compact prescribes organizational obligations to respect universally recognized human rights including rights to unionize, work, get paid decently, and be treated fairly. Since the legal abolition of slavery in the United States (and in most countries), the United States has added the right to equal opportunity - the right to be treated as an equal. This right does not imply that all of us are equal, an egalitarian claim sometimes proffered by neo-Marxists. It is rather the right to an equal chance to education, work, job opportunities, and political office. ${ }^{28}$ Finally, at least in this century, some argue that as human beings we have the right to a liveable environment. $^{29}$

According to many rights theorists, ${ }^{30}$ if the notion of basic human rights is to make sense, that is, if it is at least plausible that every human being, or every adult sane human being, has basic human or moral rights just because they are human beings, then they must be thought of as inalienable, that is, built into who we are. So even if you were to sell yourself into slavery you always have an inexorable claim to freedom. Moreover, Gewirth and Werhane and others ${ }^{31}$ argue that any right claim entails equal respect for those same rights of others. If I make a claim that I have the right to free speech, for example, and that is to make any sense as something more than a silly declaration, then that claim entails that others, all others, have equal claims to free speech. Thus as a rights claimant I have obligations to respect these rights in others. Conversely, if I have responsibilities to respect human rights or at least basic human rights, and ordinarily we would argue that every individual does, then as a human being I also have equal claims to those rights and their protections myself. Thus, according to this argument, human rights are not merely entitlements; they are reciprocal relationships and reciprocal obligations between human rights claimants.

Finally, since the idea of a human right is a relatively new and an aspirational philosophical notion, one might argue that human rights or moral rights, developing relatively late in the history of ideas, are merely socially-constructed ideas and have no ontological basis in human nature (however one defines that term). Indeed, we have expanded and redefined the nature and scope of basic human rights since their original conception by Locke

\footnotetext{
26 Robert Nozick, Anarchy, State and Utopia (New York: Basic Books, 1974).

27 Michael Walzer, Spheres of Justice (New York: Basic Books, 1994).

28 See, e.g., Ronald Dworkin, Taking Rights Seriously (Cambridge: Harvard University Press, 1977); Ronald Dworkin, Justice for Hedgehogs (Cambridge MA: Belnap Harvard University Press, 2011).

29 William T Blackstone, Environmental Crisis (Athens GS: University of Georgia Press, 1974).

30 Alan Gewirth, Reason and Morality (Chicago: University of Chicago Press, 1978); Patricia H Werhane, Persons, Rights, and Corporations (Englewood Cliffs NJ: Prentice-Hall, 1985); H L A Hart, 'Are There Any Natural Rights?' (1955) Philosophical Review 64; David Lyons, 'The Correlativity of Rights and Duties' (1970) 4 Nous 45; James Griffin, On Human Rights (Oxford: Oxford University Press, 2008).

31 Ibid; Shue, note 5.
} 
and others. But even if human rights are social constructions, that is, socially-developed principles that do not necessarily have a ground in human nature, they still set up normative standards that are at least candidates for general principles that should be ascribed to, and respected by all those individuals we designate as human beings. Thus at a minimum, human rights are aspirational moral rights claims. ${ }^{32}$

The subject reference of human rights discourse is ordinarily individual human beings. So how does this translate to organizations such as corporations? This issue leads us to the Guiding Principles and the argument that corporations have responsibilities to respect human rights in all the communities in which or with which they do business. If these are merely societal expectations, then the moral force of the Guiding Principles is watered down. This may have been the intent, but it dilutes what appear to be strong imperatives for global enterprises. On the other hand, if corporations have such responsibilities and obligations as spelled out in the Guiding Principles, and if these are normative responsibilities, as many have argued, ${ }^{33}$ then the Guiding Principles appear to assign some form of moral agency to corporations. Thus we are lead to the question, is a corporation a moral person or some form of moral agent?

\section{The Status of Corporate Moral Agency}

There is a plethora of literature on corporate moral personhood and corporate moral agency with arguments on many sides of this difficult issue. I shall only touch on general theses within this debate and only to the extent as they can inform the question assessed in this paper.

As Michael Phillips has pointed out, there are at least three conceptions of the corporation. ${ }^{34}$ First, there is the legal theory (Phillips calls this the 'concession theory') wherein firms are artificial persons existing as such only under the law. ${ }^{35}$ Second, as expressed in Citizens United, there is the aggregate theory-that corporations and other so-called organizations are merely aggregates or 'associations of individuals' ${ }^{36}$ that band together and call themselves organizations. This contention is based on the observation that a corporation does not exist autonomously. We cannot draw their portrait, shake hands with them, ask them to parties, or allow them to vote. There is no single phenomenon to perform any of these and other tasks we expect from individual persons. The 'corporation' is merely a shorthand to refer to particular sets of aggregates or collections of individuals. Corporations then lack status as independent entities. Thus, according to this position, the definition of a corporation as a legal person is merely a convenient fiction to try to hold these organizations legally liable. But when one sues a

\footnotetext{
32 Patricia H Werhane and Tara Radin, Employment and Employee Rights (Malden, Oxford, Melbourne: WileyBlackwell, 2003); Patricia H Werhane and Thomas Wren, 'Human Rights as Social Constructions' (2014) Listening 121.

33 Arnold, note 10; Wettstein, note 4 and note 11; John D Bishop, 'The Limits of Corporate Human Rights Obligations and the Rights of For-Profit Corporations' (2012) 22 Business Ethics Quarterly 119.

34 See also Orts, note 21.

35 Michael J Phillips, 'Corporate Moral Personhood and Three Conceptions of the Corporation' (1992) 2 Business Ethics Quarterly 437.

36 See Citizens United v Federal Election Commission, note 21, 876.
} 
corporation, for example, one is in fact suing a large group of individuals who manage, work for, and offer legal counsel to that aggregate. ${ }^{37}$ From this it follows that corporations, as fictions, have no moral status. Thus, from that view, a document such as the Guiding Principles is really prescribing obligations to clusters of individuals. Only the individual constituents who identify themselves as part of this organizational fiction can be held morally responsible and can be said to have rights. The corporation itself has no such obligations, since it does not exist as an independent being that could have such responsibilities.

That view is partially correct. But when it is carried to its logical conclusion, significant difficulties arise. It is true that there is no physical entity, The Corporation, with whom I can shake hands, ask to dinner or graphically picture. At the same time, corporations act. They do not act literally, but agents act on behalf of the corporation, in its name, and representing its decision processes, goals, and policies. Indeed, it has been argued that most corporations have an organizational culture and most likely a dominant logic, that is, '[internal corporate] mental maps developed through experience in the core business and $\ldots$ as the way in which managers conceptualize the business and make critical resource allocation decisions'. ${ }^{38}$ The result is that many corporate behaviours are non-distributive, that is, they are ascribable to that entity, despite its non-physical status, and not necessarily distributable to those agents who created and sustained those behaviours on behalf of the organization or because of its dominant logic. Corporations do act collectively, and, as a consequence, we do hold corporations morally as well as legally responsible, and not merely the individuals who participated in these decisions, both for untoward behaviours and projects that create value. Thus the prescriptions of the Guiding Principles make sense, but only if we can make a case for some sort of corporate moral agency.

A third conception of the firm is what Phillips calls the 'real entity view', which holds that corporations are real entities, not just artificial fictions created by law. ${ }^{39}$ The 'real entity view' was made well-known by Peter French, who argued that corporations, like human beings, are moral persons. ${ }^{40}$ This thesis has also been adopted by Denis Arnold, ${ }^{41}$ who then uses this as the basis for defending corporate moral responsibilities to respect human rights. I would argue that this is too simple. It dismisses a number of good reasons for questioning this proposition. First, corporations by themselves are not independent agents. They cannot literally act, but only 'act' vicariously through individual agents. Thus they do not have the status of human beings who can act independently and take responsibility, or not, for their actions. Second, as I contended earlier, corporate moral personhood gives to these organizations too much in the way of power.

French does not argue that corporations are biological persons. They are not. But he claims that their intentional decision-making structures are sufficiently similar to human

\footnotetext{
37 See, e.g., Manuel Velasquez, 'Why Corporations Are Not Morally Responsible for Anything They Do' (1983) 2 Business and Professional Ethics Journal 1-18; Manuel Velazquez, 'Debunking Corporate Moral Responsibility' (2003) 13 Business Ethics Quarterly 531.

38 C K Prahalad and R A Bettis, 'The Dominant Logic: A New Linkage Between Diversity and Performance' (1986) 7 Strategic Management Journal 485, 490.

39 Phillips, note 25, 440.

40 Peter French, 'The Corporation as a Moral Person' (1979) 16 American Philosophical Quarterly 208.

41 Arnold, note 10, 387-8.
} 
intentionality as to ascribe to corporations identities as moral persons. But notice that the alleged intentional decision-making structure of an organization, while appearing similar to individual intentionality, is a result of a collection of individual and group decisions. The corporation itself does not make decisions; agents make decisions on behalf of that organization. ${ }^{42}$ Firms, then, are intentional systems, displaying characteristics of intentional independent moral agents, but their 'intentions' are outcomes of human intentional agent behaviours. Corporate moral personhood ascribes to collectives the same attributes as we ascribe to individuals, but the former lack the autonomy or independence to function as independent entities. Human persons are what some have called 'non-eliminable moral agents' because no one can deny their moral agency even if we lock them away or even if I, as a moral agent, sell myself into slavery. That was Locke's point — as adult sane humans we are 'by nature', if you like, able to make choices and take responsibility, and thus have inexorable and inalienable claims to basic rights, even if we try to abrogate these claims, and even if rights are merely social constructions. But corporations are eliminable moral agents, because even as distinct abstract entities they do not and cannot act independently of those who act on their behalf. Corporations, then, like other collectives, depend on the 'strings' pulled by others, even though those strings appear to be pulled by corporate missions and goals, organizational culture, a dominant logic, and other organizationally structured phenomena that trace their origins to individual decision-making and behaviour.

As Jeffrey Nesteruk reminds us, a corporation is a socially-constructed human artefact. So the way we think about the firm affects its normative implications. ${ }^{43}$ Nevertheless, we cannot socially construct it as a moral person, because it cannot act autonomously. As socially-constructed phenomena corporations are treated as single entities, as collectives, not merely collections of individuals. Webster's Dictionary defines a collective as 'denoting a number of persons or things considered as [and acting as] one group or whole'. ${ }^{44}$ Corporations are collectives because not all their choices and actions are distributable to their constituents. Of course in very small companies and small entrepreneurships, this is ordinarily not true. But as Christopher McMahon has argued, this does not imply that any corporation is a moral person. ${ }^{45}$ Rather, a corporation, particularly one of any size, is a socially-constructed non-physical phenomenon. It cannot act on its own, but this does not diminish its collective nature and the non-redistributable content of much of its behaviour and decisions for which we hold a corporation responsible.

\section{Corporate Moral Agency and Moral Rights}

Do corporations have moral rights? David Ozar once argued that while corporations may have conventional rights, by law, they have no claims to moral rights. However while

42 Werhane, note 30.

43 Jeffrey Nesteruk, 'The Moral Status of the Corporation: Comments on an Inquiry' (1992) 2 Business Ethics Quarterly 461.

44 Merriam-Webster Dictionary, 'Collective', Merriam-Webster (n.d.), http://www.merriam-webster.com/dictionary/ collective (accessed 23 July 2015).

45 Christopher McMahon, 'The Ontological and Moral Status of Organizations' (1995) 5 Business Ethics Quarterly 541. 
corporations do not have such moral rights, he argues that 'those persons whose acts have originally constituted the corporation as a moral agent may well have [moral] rights which would be violated if the conventional rights of the corporation were changed or terminated without their participation'. ${ }^{46}$ Similarly, Tom Donaldson once contended that corporations are moral agents, but not moral persons. Thus they are not subject to rights claims, but as moral agents have to bear responsibilities for their actions. ${ }^{47}$ These are interesting ideas that give us the nub of a response to the worry about corporate moral agency and the question of corporate moral rights. Still, neither addresses clearly the actual status of the corporation as either a collective moral agent, an aggregate, or merely as convenient legal shorthand to which to ascribe liabilities.

A propitious way to think about corporate moral agency is to think of corporations and other similarly-structured organizations as 'intentional systems'. ${ }^{48}$ That is, such organizations exhibit behaviours to which we ascribe intentionality, even though they are not persons. We often expect corporations to act as moral agents and respect human rights, even though they are merely abstract legal entities. But these de facto ascriptions and expectations alone are not enough to make sense of corporations as moral agents.

Larry May has described corporations as 'vicarious moral agents'. ${ }^{49}$ That is, we ascribe to them moral agency but this ascription is a vicarious result of individual moral agents acting as agents for and on behalf of the corporation. Another way to describe this phenomenon is in terms of primary and secondary actions. Human beings, as non-eliminable moral agents are capable of voluntary autonomous choices and actions. But collectives such as corporations depend on their constituents and agents to act on their behalf. Moreover, these activities on behalf of the company are expected to be in line with the corporate mission, goals, its dominant logic, etc. So these decisions and actions are ascribed to the organization, even though the organization did not literally act. These are collective actions to which we hold the corporation responsible, and often these are non-redistributable to the multitude of individuals and groups of individuals who came to these decisions. Thus corporations are secondary moral agents. As secondary actors, corporations are dependent on the input of their constituents and agents. As moral actors, they are dependent on the moral input of these constituents and agents. As I have argued:

[t]his form of moral agency [secondary moral agency] ... is dependent upon the moral input of constituents without which corporations cannot and do not take moral considerations into account. ... [C]orporations do not always "respond" positively or even negatively to moral pressures, because corporate moral agency is not independent of the moral input of their constituents. [T] hus moral reactions of persons are necessary, (but not sufficient) for collective moral reactions. ${ }^{50}$

Because of the non-distributive character of many corporate actions, a corporation is a collective, not merely an aggregate of individuals. It functions as a non-physical,

\footnotetext{
46 David Ozar, 'Do Corporations Have Moral Rights?' (1985) 4 Journal of Business Ethics 277.

47 Tom Donaldson, 'Moral Agency and Corporations' (1980) 10 Philosophy. In Context 54, 58-59.

48 Werhane, note 30.

49 Larry May, 'Vicarious Agency' (1983) 43 Philosophical Studies 69.

50 Werhane, note $30,58$.
} 
non-psychic entity - a unit which is capable of secondary moral and immoral action. Thus we can hold corporations morally responsible, and their agents as well. ${ }^{51}$

If it makes sense to ascribe moral agency, albeit secondary moral agency, to corporations, then one has to conclude that they have some claims to moral rights. This is because, by definition, if the notion of rights makes sense, moral agency entails claims to moral rights. Eric Orts and Amy Sepinwall have advanced a similar distinction with respect to corporate rights. While not claiming that corporations are autonomous moral persons, they make the distinction between '... primary and secondary corporate rights. Primary rights are those held by the corporation (or other organizational person) in the first instance-e.g., rights of political speech in Citizens United. Secondary rights are those the corporation inherits from the rights of some individuals-e.g., rights of religious freedom'. ${ }^{52}$ I would argue that both of these sets of rights are, in my nomenclature, secondary moral rights, some of which, in the United States, have been granted legal status as well.

It follows that as intentional systems and secondary moral agents, corporations have secondary moral rights as collectives. But secondary moral rights are rights ascribed to a collective because its rights and actions are derived from a collection of individual rights and actions of moral agents, even though, in many instances, we cannot trace those origins. Moreover, because corporations are not autonomous moral agents and cannot literally choose, act, or administer their own rights claims, these secondary collective moral rights are derivative from individual moral rights and do not supersede or take precedence over individual rights. The status of corporations as legal persons in some legal systems, then, does not entail corporate moral personhood, nor should it.

\section{What is the Extent of Corporate Moral RighTS AND DUTIES?}

In a recent article, John Douglas Bishop argues that 'corporations only have legal rights (and do not have any inherent rights similar to human rights ...)' ${ }^{53}$ The previous arguments question that conclusion. However, Bishop proposes some interesting suggestions as to the scope of corporate obligations that, I assume, are to be spelled out by law. Agreeing with Ruggie, he argues that corporations should not get involved in those duties to protect (as opposed to respect) human rights that are now limited to government, such as policing, political interference, and even health and educational initiatives. ${ }^{54}$ This is because corporations are 'specialized' economic entities and have no business engaging in the politics or national welfare of a nation-state (and neither do individuals or other nation-states, we might add). Michael Santoro has argued for an

\footnotetext{
51 This conclusion raises other ethical issues that are topics for another essay. When an agent or employee acts on behalf of a company and these actions produce untoward consequences, is that persons or group of persons, as well as the company responsible? I would label this the 'Eichmann problem', the infamous Nazi who, when testifying at his trial, claimed he was just following orders on behalf of the Nazi regime. Thus, he argued, he was not personally responsible. See Hannah Arendt, Eichmann in Jerusalem (New York: Viking Press, 1963, 1964).

52 Eric Orts and Amy Sepinwall, 'Privacy and Organizational Persons' (2015) 99 Minnesota Law Review 2248.

53 Bishop, note 33, 129.

54 Ibid.
} 
expansive view of the human rights duties of corporations to include even situations where corporations are themselves not directly or indirectly involved in the human rights violation. ${ }^{55}$ Andreas Scherer and Guido Palazzo, as well as Dirk Matten and Andrew Crane, have also advanced the notion of 'political corporate social responsibility' whereby companies are seen as political actors deeply involved in the governance of the global marketplace. ${ }^{56}$ Such views, however, insufficiently account for the expansion of corporate rights that would accompany such duties. In Bishop's words, 'Corporations have no obligation to ensure human rights. To have such obligations, corporations would need many rights that ought to be reserved only for governments'. ${ }^{57}$ Just because a company has economic power does not give them what might be branded as neo-colonial rights to become politically engaged.

In fact, it is difficult for a global corporation not to become politically engaged, and there is a fine line between respecting human rights and political engagement. For example, one of the unresolved (and I suggest, unresolvable) issues in the case of Shell and its oil fields in the Ogoni region in Nigeria was whether or how it should become involved in the politics of the region that led to the unconscionable assassination of Ken Saro-Wiwa and eight other dissidents by the Nigerian government. ${ }^{58}$ It is impossible to defend all of Shell's actions in that oil field or to condone Shell's acceptance of Nigerian government protection of its operations. Still, were Shell's obligations as a company to interfere, bad as it was, with government actions of that country? Despite media and public outcries criticizing their non-interference in the treatment of the Nigerian dissidents, such interference would have 'smelled' like neo-colonialism, no matter how well-meaning or effective it would have been. Thus one has to take care in ascribing too much in the way of obligations (and thus rights!) to firms, particularly when they have the finances and power to 'improve' human rights conditions in a host country.

In addition to avoiding political engagement, as secondary, not primary (human) moral agents, the breadth and scope of corporate rights is limited to, and is to be less than, the breadth and scope of individual rights. The rights to survival and social engagement are limited to what a company does best in the economic arena. Its rights to free speech should be limited to the equal rights of individuals who may or may not have the economic largesse to broadcast their points of view. One of the issues in the Citizens United case is that this decision gives companies the permission to use their economic resources in political campaigns, resources that most individuals cannot compete with,

\footnotetext{
55 Michael A Santoro, China 2020: How Western Business Can—and Should—Influence Social and Political Change in the Coming Decade (Ithaca: Cornell University Press, 2009); Michael A. Santoro, 'Post-Westphalia and its Discontents: Business, Globalization, and Human Rights in Political and Moral Perspective' (2010) 20(2) Business Ethics Quarterly 285.

56 Andreas G Scherer and Guido Palazzo, 'Toward a Political Conception of Corporate Responsibility: Business and Society Seen From a Habermasian Perspective' (2007) 32(4) Academy of Management Review 1096; Andreas G Scherer and Guido Palazzo, 'A New Political Role of Business in a Globalized World: A Review and Research Agenda' (2011) 48(4) Journal of Management Studies 899; Dirk Matten and Andrew Crane, 'Corporate Citizenship: Toward an Extended Theoretical Conceptualization' (2005) 30(1) Academy of Management Review 166.

57 Bishop, note 33, 141.

58 William Newburry and Thomas Gladwin, 'Shell and Nigerian Oil' in Thomas Donaldson, Patricia H Werhane, and Margaret Cording (eds.), Ethical Issues in Business (Upper Saddle River NJ: Prentice-Hall, 2002) 522-41; Center for Constitutional Rights, 'Factsheet: The Case Against Shell', Center for Constitutional Rights (24 March 2009), http:// www.ccrjustice.org/learn-more/faqs/factsheet\%3A-case-against-shell-0 (accessed 23 July 2015).
} 
thus giving companies more in the way of political influence than ordinary humans. This belies the idea the corporations are merely secondary, not primary moral agents.

In summary, as secondary moral agents, corporations (and other organizations) have, or should have, limited rights (i) not exceeding those of individuals and (ii) restricted to economic, not political engagements.

\section{Conclusion}

The specifications of the Guiding Principles that corporations have a responsibility to respect human rights and 'to mitigate adverse human rights impacts that are directly linked to their operations, products or services by their business relationships, even if they have not contributed to those impacts' are valid proposals if and only if there are reciprocal responsibilities to respect corporate rights on the part of other individuals and organizations with whom the corporation engages or affects. But note the proviso that corporate rights are secondary rights and not equal in breadth or scope to human rights.

There are two more provisos, scarcely mentioned in the Guiding Principles. First is the question of the extent of corporate obligations. Human persons, who claim that they have basic rights, have, in theory, obligations to respect equally those same rights for everyone else. But that is a normative claim. In fact, no one individual can fulfil those obligations completely and universally, simply because of our fallibility. So the question is, what is the scope of corporate obligations? Sir Geoffrey Chandler once proclaimed that 'the responsibility of a company [is] for the totality of its impact .... ${ }^{59}$ But this may be expecting too much from a corporation just as that expectation would be equally too much for an individual. One needs to take care in extending equal human rights to corporations when those allow the influence of undue power or economic largesse appear to be a form of neo-colonialism.

It follows that if corporations are secondary moral agents, their rights claims are not as extensive, nor can they be greater than, individual rights claims. So the rights-obligations reciprocal relationships are more complex when they are between a firm and individuals than, say, between individuals or between corporations. Many of these rights are spelled out legally, as we explicated earlier in this essay. Still some give corporations too much in the way of legal rights, and those challenges such as questions about the Citizens United decision will continue. ${ }^{60}$ I would suggest that this is because of a fear of giving business corporations too much in the way of power and expanding their abilities to interfere in politics and public policy. The Shell-Nigeria case is a good reminder of those kinds of issues. Thus corporate secondary moral rights are extensively less than basic human moral rights. This is an imbalance, but a proper one, because of the nature and size of corporate agency and the prioritization of fairness over equality.

Finally, there is a 'so what?' to this analysis. How much does it matter, practically, and in the context of the Guiding Principles, whether or not we ascribe moral personhood to corporations and extend their access to rights? I would conclude that this matters deeply

59 Sir Geoffrey Chandler, 'Introduction: Defining Corporate Social Responsibility' (2001) Ethical Performance Best Practices.

60 See, e.g., Elizabeth Pollman, 'Reconceiving Corporate Personhood' (2011) Utah Law Review 1629. 
for a number of reasons. First, it is what Gilbert Ryle once called a 'category-mistake' to ascribe personhood to collectives such as corporations. ${ }^{61}$ Corporations are not individual autonomous non-eliminable agents, and to make that ascription giving corporations the status of persons not only conflates two distinct kinds of distinct phenomena, but wrongly extends to corporations much too much in the way of rights and power. Indeed, one may question the various United States court decisions granting corporations freedom of speech and lately, rights to virtually unlimited ability to contribute to political campaigns as overextending the bounds of collective power. ${ }^{62}$ Second, there are lessons to be learned from the formation of the British East India Company whose unlimited and unbridled power allowed it to become one of the greatest colonizers in history. Without being held morally responsible for their actions, as the Guiding Principles now prescribe, the East India Company ran amok in most of what is now modern India with almost complete disregard for the local peoples.

Third, we want to argue with the Guiding Principles that corporations have obligations to respect human rights and mitigate their violations, within their purview as business organizations. If they are merely legal entities, so-called voluntary responsibilities only extend to nation-states where there is a well-defined rule of law. Thus the global intent of the Guiding Principles is undermined. By ascribing to corporations secondary moral agency, we are able to justify the bases for the prescriptions in the Guiding Principles. That justification was missing in Ruggie's outline of the Guiding Principles, and in some other discussions of the Guiding Principles, many of which just assume that companies have these responsibilities without inquiring into the basis for that conclusion. Arnold, for example, states that 'Even if one rejects that view that corporations are properly regarded as intentional agents and duty-bearers, one can readily acknowledge that all corporations are populated by individual employees, who are agents, and, as such, duty bearers. ... [T] [Tose duties carry over to their work for companies'. ${ }^{63}$ But this conclusion begs the question. It assumes that if corporations are not intentional agents, they are aggregates of individuals. But as organizations, corporations would have no rights or responsibilities beyond obeying the law. This is surely not the intention of the Guiding Principles. The argument that corporations are secondary moral agents, then, provides a moral basis for the prescriptions in the Guiding Principles that corporations have responsibilities to respect human rights, avoid rights infringements, and mitigate their abuses within their purview. These are global voluntary responsibilities that have moral force without imagining that corporations are fully-fledged moral persons and do not unduly extend corporate responsibilities to political action.

\footnotetext{
61 Gilbert Ryle, The Concept of Mind (London: Hutchison's University Library, 1949).

62 See, e.g., Elizabeth Pollman, 'A Corporate Right to Privacy' (2014) 99 Minnesota Law Review 27 on whether corporations should be granted rights to privacy.

63 Arnold, note 10, 388 .
} 